PELATIHAN DIGITAL MARKEING DALAM UPAYA PENGEMBANGAN USAHA BERBASSTEKNOLOGI PADA UMKM DI DESA SAYANG KECAMATAN J ATINANGOR

\section{Elisa Susanti}

Fa kultas IImu Sosia I dan IImu Politik, Universitas Padjajdran

Article history

Rec eived : 8 Maret 2020

Revised : 20 Maret 2020

Accepted : 26 Maret 2020

*Correspond ing a uthor

email: elisa_susanti@yahoo.com

No. doi: https://doi.org/10.24198/sawala.v1i2.26588

\begin{abstract}
Abstraksi
Salah satu permasalahan yang dihadapi oleh UMKM di Desa Sayang adalah masalah pemasaran dan keterampilan menggunakan teknologi. UMKM di Desa Sayang memerlukan pengembangan usaha berbasis teknologi sehingga dapat bersaing dengan usaha-usaha baru yang bersifat online. Tujuan dari penulisan paper ini adalah 1) Mengidentifikasi penggunaan media pemasaran pada UMKM di Desa Sayang Kecamatan Jatinangor 2) Menggambarkan upaya pengembangan usaha berbasis teknologi pada UMKM Desa Sayang Kecamatan Jatinangor melalui pelatihan digital marketing. Metode yang digunakan dalam identifikasi penggunaan media pemasaran adalah dengan observasi, wawancara, penyebaran kuisioner dan FGD. Metode yang digunakan dalam upaya pengembangan usaha berbasis teknologi adalah metode pendidikan masyarakat dan pelatihan. Materi-materi dalam upaya pengembangan usaha berbasis teknologi pada UMKM Desa Sayang melalui pelatihan digital marketing meliputi : 1) Menumbuhan jiwa kewirausahaan dan memberikan insipirasi dari keberhasilan bisnis online, 2) Sharing session, 3) Pelatihan digital marketing (menggunakan grab food dan go food). Hasil identifikasi menunjukkan bahwa banyak UMKM di Desa Sayang menggunakan teknologi sederhana dalam pemasaran, yaitu didominasi dengan media Whatsapp dan Facebook. Bahkan masih banyak UMKM yang menjalankan usahanya secara offline tanpa bantuan teknologi. Hasil evaluasi dari kegiatan pelatihan digital marketing menunjukkan bahwa kegiatan ini mendapatkan tanggapan yang positif, dinilai dapat memberikan wawasan dan ilmu, dan memberikan inspirasi. Hampir seluruh pelaku usaha ingin mempraktekan bisnis online ini dalam pengembangan usa hanya.
\end{abstract}

Kata kunci : Digital Marketing, Pelatihan Digital Marketing, UMKM. 
still many MSMEs that run their businesses offline without the help of technology. The results of evaluations of digital marketing training show that this training obtained some positive responses, because the training provided insight, knowledge, and inspiration. Almost all business people want to implement this online model in developing their business.

Keywords : Digital Marketing, Digital Marketing Training, MSME.

\section{PENDAHULAN}

Banyak

mengemukakan pentingnya UMKM dan pentingnya penggunaan teknologi dalam melakukan usaha bagi UMKM. Usaha kecil dan menengah (UKM) memainkan peran penting dalam semua ekonomi di dunia, karena terkait dengan penciptaan lapangan kerja, pengentasan kemiskinan, kontribusi pada inovasi dan produk domestik bruto suatu negara. Namun banyak dari bisnis UMKM menghadapi tantangan dan sering gagal dalam waktu singkat. Tantangan yang dihadapi oleh UMKM ini diantaranya adalah terkait dengan produk dan cara pemasaran yang efektif. (Cant \& Wiid, 2016). Permana (2017) juga mengemukakan bahwa sektor UMKM memiliki peran yang sangat strategis bagi perekonomian Indonesia karena sektor ini merupakan salah satu sektor ekonomi yang berkontribusi besar bagi pembentukan PDB. Sela in itu juga, UMKM merupakan salah satu altematif solusi bagi permasalahan-pemasalahan sosial seperti kemiskinan dan pengangguran.

Terdapat tantangan baru yang dihadapi dalam dunia usaha karena terkait dengan perkembangan teknologi informasi dan komunikasi. Pola pemasaran dalam bisnis telah berubah dengan cepat. Keberadaan intemet saat ini mengarah kegiatan komersial dimana pelanggan dapat melakukan transaksi melalui berbagai aplikasi. (Kumiawan \& Asharudin, 2018). Intemet telah mengubah cara organisasi menyusun din, dan mengubah hubungan pelanggan dengan perusahaan. Penggunaan intemet ini memungkinkan informasi mengalir bebas antara pembeli dan penjual, menghilangkan biaya dari proses bisnis dan meningkatkan pilihan pelanggan. (Rowan, 2002). Adopsi teknologi untuk pemasaran sangat penting untuk kelangsungan usaha kecil. (Alford \& Page, 2015). Dengan demikian, diperlukan perhatian terhadap pengembangan UMKM. Strategi pemasaran online berpengaruh positif terhadap peningkatan laba UMKM. (Setiawati \& Wid ya rtati, 2017)

Sebenamya, telah terdapat keinginan yang kuat dari UMKM untuk mengadopsi teknologi dalam pemasaran. (Alford \& Page, 2015). Namun terdapat permasalahan yang dihadapi oleh UMKM sehingga pemanfaatan teknologi ini kurang berjalan dengan baik. Diketahui bahwa UKM tidak mengikuti perkembangan digital, terutama karena kurangnya pengetahuan tentang pemasaran digital (Alford \& Page, 2015 ; Taiminen \& Karjaluoto, 2014), dan terdapat ketidakmampuan untuk mengukur laba atas investasi (Alford \& Page, 2015). Cant \& Wiid (2016) juga mengemukakan bahwa pemilik UMKM kebanyakan menggunakan tradisional berupa media cetak. Namun sejumlah pelaku usaha percaya bahwa penggunaan pemasaran tradisional dianggap kurang efektif. Pemasaran online dan media sosial pemasaran hanya sebagai pelengkap. Dengan demikian, karena sebagian besar UKM belum menerapkan potensi penuh dari alat digital, maka tidak mendapat manfaat sepenuhnya dari perkembangan digital.

Kondisi yang terja di di Indonesia tidak ja uh berbeda dengan negara-negara lainnya. Kumiawan \& Asharudin (2018) mengemukakan bahwa tidak semua UMKM di Indonesia mampu mengubah pola pemasaran mereka kepada pemasaran digital. Faktor latar belakang pendidikan yang rendah dan kurangnya pengetahuan tentang intemet, pengembangan, dan teknologi adalah alasan belum optimalnya penggunaan pemasaran digital pada UMKM. 
Terdapat beberapa saran dan Implikasi sosial terhadap permasalahan UMKM tersebut. Cant \& Wiid (2016) menganjurkan pemilik UMKM menggunakan pemasaran online untuk melengkapi pemasaran tradisional mereka. Taiminen \& Ka jaluoto (2014) mengemukakan tentang pentingnya pengembangan UKM dengan mengadakan program pelatihan untuk membantu UMKM mengeksploitasi digitalisasi, demikian juga diperlukan dukungan dari pemenintah. Secara khusus bagi pengembangan UMKM di Indonesia, yaitu agar pelaku bisnis mengubah pola pemasaran mereka sesuai dengan perkembangan dan kemajuan teknologi di masyarakat untuk dapat bertahan hidup (Kumiawan \& Asharudin, 2018), menumbuhkan jiwa kewirausahaan di masya rakat melalui pendidikan, dukungan pemasaran bagi UMKM, dan perbaikan infrastruktur komunikasi (Permana, 2017). Apabila merujuk pada berbagai literatur tersebut, maka sangat penting untuk dilakukan pelatihan penggunaan digital marketing bagi pelaku UMKM.

Kondisi dan permasalahan yang dihadapi UMKM tersebut juga sama halnya dengan kondisi UMKM di Desa Sayang Kecamatan Jatinangor. Kajian sebelumnya tentang Desa Sayang dan desa lain di Kecamatan di Jatinangor dikemukakan oleh Mulyana (2016). Dikemukakan bahwa kurangnya modal dan keterampilan menjadi permasalahan yang paling banyak dihadapi oleh masyarakat di Desa Sayang, Desa Cilayung dan Desa Hegarmanah di Kecamatan Jatinagor. Sebenamya desa-desa ini sangat memiliki potensi karena letak geografis yang dekat dengan jalan yang menghubungkan kota-kota Bandung dengan Sumedang dan Cirebon. Dengan demikian, akses pemasaran akan menjadi lebih mudah yang juga disebabkan karena banyaknya pendatang dari luar khususnya ma hasiswa dan keluarga mahasiswa. Dikemukakan mengenai jenis pelatihan yang diberikan di Desa Sayang yaitu penyuluhan dan pengobatan gratis, penyuluhan pertanian, praktikum mahasiswa, pemeriksaan gigi, dan pelatihan wirausaha. Dikemukakan bahwa pelatihan di Desa Sayang ini masih disebut lebih sedikit jika dibanding dengan desa la innya di Kecamatan J atinangor.

$$
\mathrm{Di} \text { Desa Sayang terdapat }
$$
beberapa UMKM yang sudah dan masih ada sampai saat ini. UMKM yang ada di Desa Sayang Jatinangor dapat dikategorikan ke dalam usaha produsen dan berdagang. Usaha tersebut sebagian besar bergerak dalam bidang makanan. Selain makanan terdapat juga usaha seperti baju muslim, konveksi, dan kerajinan. Berdasarkan hasil observasi awal, diketahui terdapat beberapa masalah umum yang diha dapi oleh UMKM di Desa Sayang yaitu : kurang adanya informasi serta aksi dari para stakeholder Desa Sayang untuk membuat perkumpulan dan pelatihan terkait usaha yang ditekuni, permasalahan pemasaran produk, pelaku usaha merasa sulit untuk memasarkan dan mengembangkan usaha yang ditekuninya, dan masalah persaingan usaha dengan pendatang di Desa Sayang yang lebih maju karena lebih inovatif menggunakan teknologi dalam melakukan usahanya. Para pelaku usaha (UMKM) di Desa Sayang dihadapkan pada perubahan lingkungan yaitu di era digital. Terdapat beberapa hambatan karena keterbatasan ilmu dan keterampilan dalam menggunakan teknologi dan mengelola bisnis online.

Berdasarkan latar belakang tersebut, maka rumusan masalah dalam penulisan paper ini adalah : UMKM di Desa Sayang memerlukan pengembangan usaha yang berbasis teknologi sehingga dapat bersaing dengan usaha-usaha baru yang bersifat online. Sehingga tujuan dari penulisan paper ini adalah : 1) Mengidentifikasi penggunaan media pemasaran pada UMKM di Desa Sayang Kecamatan Jatinangor

Menggambarkan upaya pengembangan usaha berbasis teknologi pada UMKM Desa Sayang Kecamatan Jatinangor mela lui pelatihan dig ital ma rketing.

\section{KONSEP DIG TAL MARKETING}

Pemasaran digital diartikan dengan pemasaran di mana pesan dikirim menggunakan media yang tergantung pada transmisi digital. Namun sejauh ini, intemet merupakan media digital paling signifikan. (Bird, 2007). Banyak sekali tokoh yang mengemukakan bahwa tejadi perubahan dalam pemasaran yang 
disebabkan karena perkembangan teknologi, terutama intemet. Keuntungan dari digital marketing menggunakan intemet adalah lebih mudah, lebih murah atau lebih cepat untuk berkomunikasi. (Ryan \& J ones, 2009 ; Bird, 2007 ; Chaffey dan Smith, 2002)

Namun pemasaran digital bukan tentang memahami teknologi yang mendasarinya, melainkan tentang memahami orang, bagaimana mereka menggunakan teknologi itu, dan bagaimana memanfaatkan teknologi untuk terlibat dengan mereka secara lebih efektif, dan harus lebih didorong oleh kualitas komunikasi daripada kua ntita snya (Taiminen \& Karjaluoto, 2014 ; Ryan \& Jones, 2009 ; Rowan, 2002).

Terdapat berbagai dimensi dari digital marketing yaitu : website, optimasi mesin pencari, periklanan berbasis klik pencarian berbayar, pemasaran afiliasi dan kemitraan, hubungan masyarakat online, jejaring social, email, manajemen hubungan konsumen (Ryan \& Jones, 2009). Media sosial juga merupakan media yang sangat potensial dan paling efektif dalam pemasaran digital untuk berbicara dengan pelanggan. (Weber, 2009).

Diperlukan upaya untuk mencapai hasil dari digital marketing. Pemasar harus memiliki strategi bisnis dalam pemasaran digital (Yasmin, et.al, 2015 ; Gibson, 2018) Yasmin et.al (2015) juga mengemukakan bahwa diperlukan upaya, percobaan dan kesalahan. Kata kuncinya adalah "uji, pelajari, dan kembangkan". Hal tersebut menupakan inti dari semua inisiatif pemasa ran digita l.

Digital marketing juga dapat membangun brand awareness, yang dilakukan dengan cara menentukan media sosial yang akan digunakan, perencanaan pesan, dan menentukan teknik bauran promosi yang akan digunakan. (Oktaviyani dan Rustandi, 2018)

Beberapa upaya telah dilakukan
meningkatkan keterampilan pemasar dalam digital marketing. Pelatihan untuk meningkatkan keterampilan dan pengetahuan pemasar telah memiliki efek positif. Melalui workshop digital marketing (penyampaian materi, diskusi dan praktik) maka pemasar lebih memahami pentingnya penggunaan media intemet untuk meningkatkan daya saing usahanya (Widyaningrum dan Bharata, 2017 ; Baladraf dkk, 2018 ). Beberapa pelatihan yang dapat dilakukan seperti alih pengetahuan dan teknologi dalam perancangan bisnis online, pemanfaatan E-Commerce yang sudah ada, pemanfaatan transaksi perbankan secara online, penggunaan Social Media dan Search Engine Optimization (SEO) dalam penjualan dan pemasaran secara online. (djamaludin dkk, 2016)

\section{METODE}

Terdapat beberapa kegiatan dengan metode yang berbeda dalam upaya pengembangan usaha berbasis teknologi pada UMKM Desa Sayang Kecamatan Jatinangor melalui pelatihan digital marketing. Secara garis besar terdapat dua kegiatan utama yaitu identifikasi penggunaan media pemasaran pada UMKM di Desa Sayang Kecamatan Jatinangor, dan kegiatan pelatihan digital marketing dalam upaya pengembangan usaha yang berbasis teknologi pada UMKM Desa Sayang Kecamatan J a tinangor.

1. Identifikasi penggunaan media pemasaran pada UMKM di Desa Sayang Kecamatan J atinangor Kegiatan identifikasi penggunaan media pemasaran pada UMKM di Desa Sayang dilakukan untuk mengetahui kondisi saat ini dari para pelaku usaha dalam memanfaatkan teknologi informasi dan komunikasi dalam menjalankan usahanya. Metode yang digunakan dalam identifikasi penggunaan media pemasaran pada UMKM di Desa Sayang Kecamatan Jatinangor adalah:

a. Observasi

Kegiatan observasi ini dilakukan pada beberapa UMKM di Desa Sayang, dilakukan untuk mengetahui cara UMKM ini melakukan usaha, berikut mengetahui berbagai pemasalahan yang dihadapi UMKM dalam berusaha.

b. Wawancara dan penyebaran kuisioner

Wawancara dilakukan kepada beberapa pelaku usaha di Desa Sayang. Melalui wawancara, diperoleh informasi secara kualitiatif 
yang tidak diperoleh melalui kuisioner. Teknik wawancara yang dilakukan adalah dengan in-depth interview. Informasi yang diperoleh dari wawancara dan penyebaran kusioner adalah mengenai : penggunaan teknologi dan infomasi dalam melakukan usaha, inftrastruktur teknologi yang dimiliki dalam menjalankan usaha, media sosial atau marketplace yang sudah digunakan, cara pemasaran yang lebih banyak digunakan, strategi pelaku usaha untuk memanfaatkan teknologi informasi dalam melakukan usaha, kesiapan SDM dalam melakukan usaha secara online, dan kendala yang dihadapi dalam melakukan usaha.

\section{c. FGD}

FGD dilakukan bersama dengan pemerintah Desa Sayang, pelaku usaha, dan tokoh masyarakat Desa Sayang. Dalam FGD ini digali informasi mengenai potensi lokal yang dimiliki oleh Desa Sayang, pemasalahan yang dihadapi oleh pelaku usaha di Desa Sayang, dan harapan dari para pelaku usaha di Desa Sayang.
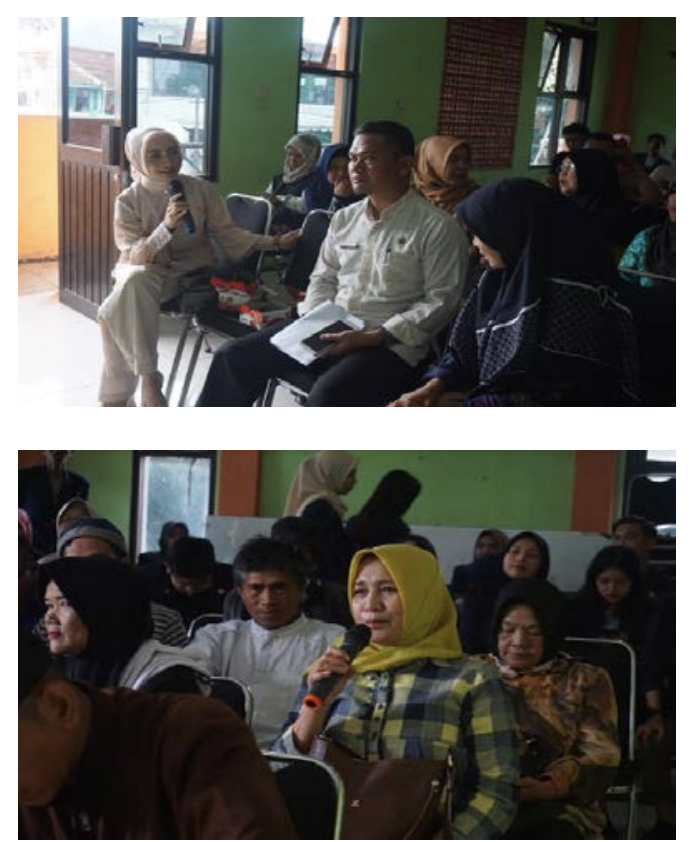

Gambar 1. FGD Untuk Mengeta hui Permasalahan dalam Berusaha pada UMKM di Desa Sayang

2. Pelatihan digital marketing dalam upaya pengembangan usaha yang berbasis teknologi pada UMKM Desa Sayang Kecamatan J atinangor.

Berdasarkan identifikasi pada tahap sebelumnya, maka penulis melakukan kegiatan pelatihan digital marketing dalam upaya pengembangan usaha yang berbasis teknologi pada UMKM Desa Sayang Kecamatan Jatinangor. Metode yang digunakan adalah pendidikan masya rakat dan pelatihan. a. Metode pendidikan masyarakat, dilakukan pada materi dasar kewirausahaan yaitu berbisnis secara online. Pendidikan masyarakat ini bertujuan untuk meningkatkan wawasan pelaku usaha mengenai kewirausahaan, terutama berbisnis secara online. Selain meningkatkan wawasan, materi ini juga dilakukan untuk memberikan semangat dan motivasi kepada para pelaku usaha di Desa Sayang.

b. Metode Pelatihan, dilakukan pada praktek mendaftarkan usaha ke grab food dan go food. Materi ini dilakukan sesuai dengan identifikasi awal dan hasil FGD bersama dengan pelaku usaha dan juga tokoh masyarakat di Desa Sayang.

3. Evaluasi Kegiatan

Evaluasi kegiatan dilakukan untuk mengetahui feedback dari masyarakat, berupa tanggapan dari pelaku usaha, tindak lanjut yang akan dilaksanakan oleh pelaku usaha, juga harapan untuk masa depan. Evaluasi kegiatan ini juga dilakukan untuk mengetahui kesesuaian antara hasil identifikasi awal penggunaan media dalam pemasaran dengan kegiatan pelatihan yang diberikan. Bentuk evaluasi kegiatan ini dilakukan dengan cara penyebaran kuisioner.

\section{HASILDAN PEMBAHASAN}

Identifikasi Penggunaan Media Pemasaran pada UMKM di Desa Sayang Kecamatan Jatinangor. Berikut dalam tabel 1 adalah hasil identifikasi penggunaan media pemasaran pada UMKM di Desa Sayang Kecamatan Jatinangor. Informasi identifikasi ini bersumber dari pelaku usaha yang mengikuti pelatihan. 
Tabel 1 Hasil Identifikasi Penggunaan Media Pemasaran pada UMKM di Desa Sayang Kecamatan Jatinangor (pada peserta pelatihan)

\begin{tabular}{|c|c|c|c|c|c|}
\hline Peserta & $\begin{array}{l}\text { Kepemilik- } \\
\text { an Wifi } \\
\text { di rumah }\end{array}$ & $\begin{array}{l}\text { Kepemilik- } \\
\text { an laptop }\end{array}$ & $\begin{array}{l}\text { Media sosial/ } \\
\text { marketplace } \\
\text { yang diguna- } \\
\text { kan dalam } \\
\text { berusaha }\end{array}$ & $\begin{array}{l}\text { Cara } \\
\text { pemasaran } \\
\text { yang lebih } \\
\text { banyak } \\
\text { dilakukan }\end{array}$ & $\begin{array}{l}\text { Kendala dalam } \\
\text { memasarkan } \\
\text { produk }\end{array}$ \\
\hline 1 & Tidak & Tidak & Tidak ada & $\begin{array}{l}\text { Secara } \\
\text { langsung } \\
\text { menggunaka } \\
\text { n gerobak }\end{array}$ & $\begin{array}{l}\text { Kesulitan } \\
\text { membuat aplikasi }\end{array}$ \\
\hline 2 & Tidak & $\mathrm{Ya}$ & WA & $\begin{array}{l}\text { Melalui } \\
\text { brosur }\end{array}$ & Banyak saingan \\
\hline 3 & Tidak & $\mathrm{Ya}$ & Bukalapak & $\begin{array}{l}\text { Lebih banyak } \\
\text { offline }\end{array}$ & - \\
\hline 4 & Tidak & Tidak & WA & Di pasar & Cuaca \\
\hline 5 & $Y a$ & Ya & Tidak ada & Offline & \\
\hline 6 & Tidak & Tidak & Tidak ada & Keliling & $\begin{array}{l}\text { Promosi dan } \\
\text { modal }\end{array}$ \\
\hline 7 & Tidak & $\mathrm{Ya}$ & WA, FB & $\begin{array}{l}\text { Dari mulut ke } \\
\text { mulut }\end{array}$ & - \\
\hline 8 & Tidak & $Y a$ & FB & $\begin{array}{l}\text { Ditawarkan } \\
\text { melalui FB }\end{array}$ & $\begin{array}{l}\text { Cari produk yang } \\
\text { tidak terlalu } \\
\text { pasaran }\end{array}$ \\
\hline 9 & Tidak & Tidak & FB & Offline & $\begin{array}{l}\text { Kurangnya } \\
\text { peminat yang } \\
\text { belum } \\
\text { mengetahui rasa } \\
\text { dan harga }\end{array}$ \\
\hline 10 & Tidak & $\mathrm{Ya}$ & WA, FB & Offline & $\begin{array}{l}\text { Kurang promosi } \\
\text { dan tenaga } \\
\text { produksi }\end{array}$ \\
\hline 11 & Tidak & Tidak & Instagram, FB & $\begin{array}{l}\text { Secara offline } \\
\text { dan online }\end{array}$ & Minat pembeli \\
\hline 12 & Tidak & $\mathrm{Ya}$ & WA & WA & $\begin{array}{l}\text { Habis kuota dan } \\
\text { keterbatasan } \\
\text { waktu dan } \\
\text { tenaga }\end{array}$ \\
\hline 13 & $\mathrm{Ya}$ & $\mathrm{Ya}$ & WA, FB & $\begin{array}{l}\text { Langsung ke } \\
\text { konsumen } \\
\text { dan melalui } \\
\text { WA }\end{array}$ & - \\
\hline 14 & Tidak & Tidak & Tidak ada & Offline & Pemasaran \\
\hline 15 & Tidak & Ya & WA & $\begin{array}{l}\text { Offline dan } \\
\text { WA }\end{array}$ & - \\
\hline 16 & Tidak & Ya & Tidak ada & Offline & - \\
\hline 17 & Tidak & Tidak & WA & $\begin{array}{l}\text { Dari mulut ke } \\
\text { mulut }\end{array}$ & - \\
\hline 18 & Ya & Tidak & WA, FB & $\begin{array}{l}\text { Offline dan } \\
\text { WA }\end{array}$ & Persaingan harga \\
\hline 19 & Tidak & $Y a$ & Tidak ada & Di warung & - \\
\hline
\end{tabular}




\begin{tabular}{|c|l|l|l|l|l|}
\hline 20 & Ya & Ya & WA, FB & $\begin{array}{l}\text { Offline dan } \\
\text { online }\end{array}$ & $\begin{array}{l}\text { Pengembangan } \\
\text { jejaring } \\
\text { pemasaran }\end{array}$ \\
\hline 21 & Tidak & Tidak & WA & $\begin{array}{l}\text { WA, telepon, } \\
\text { langsung ke } \\
\text { konsumen }\end{array}$ & $\begin{array}{l}\text { Pengemasan } \\
\text { produk, tidak ada } \\
\text { kendaraan untuk } \\
\text { keluar kota }\end{array}$ \\
\hline 22 & Tidak & Ya & WA, FB & $\begin{array}{l}\text { Membuka } \\
\text { warung dan } \\
\text { melalui } \\
\text { medsos }\end{array}$ & $\begin{array}{l}\text { Susah untuk } \\
\text { masuk ke grab } \\
\text { food dan go food } \\
\text { karena belum } \\
\text { disetujui }\end{array}$ \\
\hline
\end{tabular}

Data tersebut menupakan kondisi awal penggunaan media pemasaran, khususnya teknologi dan kondisi infrastruktur teknologi pada UMKM di Desa Sayang (pada peserta pelatihan). Berdasarkan data tersebut, diketahui bahwa infrastruktur dasar dalam penggunaan ICT dalam berusaha dinilai belum memadai. Hal tersebut dilihat dari hanya $18 \%$ pelaku usaha yang memiliki wifi di numah atau di tempat usaha. Demikian juga, tidak selunuh pelaku usaha memiliki laptop atau komputer (sebesar 59\% pelaku usaha yang memiliki laptop atau komputer). Namun, laptop atau komputer yang sudah dimiliki tersebut tidak digunakan secara maksimal. Berdasarkan data dapat diketahui bahwa terdapat pelaku usaha yang memiliki laptop/komputer namun banyak yang tidak ditunjang dengan wifi. Di sisi lain, terdapat pelaku usaha yang memiliki laptop dan memiliki wifi namun tidak menggunakan media sosial atau marketplace dalam melakukan pemasaran atau dalam melakukan usaha. Cara pemasaran yang dilakukan adalah secara offline. Demikian juga, pelaku usaha yang memiliki laptop atau computer, lebih memilih cara pemasaran melalui WA dan FB yang diakses melalui handphone. Dengan demikian, kepemilikan laptop/komputer ini tidak digunakan untuk mengembangkan usaha secara online.

Hampir seluruh UMKM masih menggunakan handphone dalam menjalankan usahanya. Media yang sering digunakan dalam pemasaran terbatas pada media sosial sehari-hari yaitu WA dan facebook, hanya sebagian kecil yang menggunakan instagram. Bahkan masih banyak pelaku usaha yang sama sekali belum menggunakan media sosial. Media online yang sering digunakan adalah melalui WA dan FB. Namun, cara pemasaran yang lebih banyak dilakukan selama ini adalah secara offline, memasarkan di warung, melalui gerobak, langsung mengunjungi konsumen.

Penulis juga melakukan identifikasi penggunaan teknologi infomasi dan komunikasi dalam pemasaran pada UMKM di Desa Sayang Kecamatan Jatinangor dengan melakukan wawancara pada beberapa UMKM. Berdasarkan wawancara dengan pemilik Keripik Bayam Raja Ratu, diketahui bahwa media promosi dan pemasaran yang pemah digunakan selama ini adalah melalui facebook, WA dan shopee. Dalam menjalankan usahanya, pemilik usaha lebih mengandalkan handphone, belum memiliki laptop atau komputer, dan juga tidak memiliki kepemilikan wifi di rumah. Kendala yang dihadapi adalah pengemasan produk, karena produk seringkali hancur ketika dikinimkan ke luar kota.

Selanjutnya, berdasarkan wawancara dengan pelaku usaha yang bergerak dalam bidang kue-kue basah dan makanan diketahui bahwa lebih banyak menggunakan pemasaran melalui Facebook dan WA. Pelaku usaha mengemukakan bahwa usahanya lebih dikenal oleh masyarakat karena masya rakat sekitar sudah mengeta huinya. Pemilik usaha ini dan juga seperti pemilik usaha makanan lainnya di Desa Sayang, kurang berfokus pada pengembangan teknologi karena produk yang dibuatnya hanya berdasarkan pesanan.

Produk yang dibuat hanya berdasarkan pesanan dan juga kendala dalam sumber daya manusia, baik pengelola aplikasi maupun pekerja untuk membuat produk, menupakan alasan 
sehingga para pelaku usaha kurang berfokus pada pengembangan teknologi. Seperti halnya pada UMKM sale pisang. Usaha ini merupakan usaha turun temurun, dengan proses pembuatan produk sale pisang yang membutuhkan waktu lama, bahan baku untuk membuat sale pisang sulit ditemukan dengan harga yang tidak menentu, dan proses pengolahan masih menggunakan alat tradisional. Dengan kondisi seperti itu, maka pelaku usaha tidak terlalu berfokus pada pengembangan teknologi dalam pemasarannya. Meskipun demikian, UMKM ini sudah pemah menggunakan ICT sebagai strategi untuk meningkatkan usaha yaitu dengan menggunakan media website yaitu di tahun 2015. Namun demikian, UMKM ini dinilai belum cukup siap untuk menggunakan ICT sebagai penunjang usaha.

Kendala kekurangan pekerja dan keterbatasan pembuatan produk yang dihasilkan juga dihadapi oleh usaha Onig in Bento. Pemilik usaha mengemukakan bahwa kurang memiliki keterampilan dalam menggunakan teknologi dan hanya memiliki 1 karyawan sehingga akan merasa agak sulit apabila pesanan melebihi dari 100 onigiri. Meskipun demikian, pemilik usaha ini sudah mencoba menggunakan Instagram, facebook, dan go-food namun kurang bejalan karena keterbatasan keterampilan dalam penggunaan aplikasi tersebut.

Terdapat juga UMKM yang sama sekali belum menggunakan teknologi dalam pemasaran. Kondisi ini banyak dihadapi oleh UMKM di Desa Sayang, sehingga cara pemasaran lebih dilakukan dengan cara tradisional/offline. Seperti halnya UMKM roti di Desa Sayang. Pemilik usaha tidak menggunakan ICT dan tidak memiliki strategi meningkatkan usaha dengan menggunakan ICT karena terkendala kompetensi dalam menggunakan ICT. Karyawannya pun jumlahnya sedikit serta tidak memiliki kompentensi dalam penggunaan ICT. Sejak awal mendirikan usaha dari tahun 2017 hingga kini, UMKM ini masih mengandalkan proses tradisional dari awal proses pembuatan hingga pemasaran. Maka seringkali banyak roti yang tidak laku dipasaran basi lalu kemudian dibuang. Hal ini karena tidak ada perkiraan produksi roti yang akan dibuat. UMKM ini menyebarkan informasi produk hanya di lingkungan sekitar usaha melalui warung dan juga penjual roti. Akan tetapi, pemilik usaha memiliki kemauan untuk meningkatkan usaha dengan ICT apabila ada pihak yang mengajarinya. la ingin mencoba menggunakan ICT agar usahanya lebih berkembang dan banyak yang mengeta hui apalagi di era ekonomi digital saat ini, banyak pesaing yang sudah menggunakan ICT dalam menjalankan usahanya. Oleh karena itu, ia membutuhkan informasi terkait penggunaan ICT dan informasi mengenai cara meningkatkan usaha di era ekonomi digital.

Meskipun terdapat banyak UMKM yang belum maksimal menggunakan teknologi dalam berusaha, namun terdapat juga UMKM yang sudah berhasil menerapkan teknologi dalam pemasaran dan dalam pengembangan usahanya. Seperti UMKM Neng Katsu. Catering Neng Katsu menggunakan instagram dan line sebagai media usaha serta melakukan lebih banyak promosi sebagai strategi untuk meningkatkan usahanya seperti paid promote dan hastag. Informasi dan target pasar juga diperlukan dalam peningkatan usaha terutama untuk mengetahui sumber dan harga bahan baku yang perlu dibeli, apa yang dibutuhkan konsumen dan bagaimana daya beli masyarakat terhadap produk usaha yang sedang dilakukan. Dalam menjaga keamanan produk yang dipasarkan lewat media sosial instagram sendin, Neng Katsu memberi watemark pada setiap foto yang diunggahuntuk menghindari pencurian gambar. Adapun faktor yang menyebabkan umkm catering Neng Katsu dapat menggunakan teknologi dalam berusaha, ka rena pemilik usaha baru saja menyelesaikan pendidikan sarjana di jurusan Administrasi Bisnis, mampu menggunakan teknologi dan bisa mengoperasikan media sosial, serta sudah memanfaatkan layanan intemet dalam menjalankan usahanya. Untuk kendala, pemilik usaha catering Neng Katsu merasa ada banyak saingan sehingga untuk mengatasi hal tersebut Neng Katsu menghargai produknya sesuai dengan budget ma hasiswa. 
Berdasarkan hasil wawancara dan juga identifikasi a wal mela lui kuisioner, UMKM di Desa Sayang dapat dikelompokkan berdasarkan penggunaan ICT dalam melakukan usaha, yaitu :

- UMKM yang sama sekali belum menggunakan ICT dalam melakukan usaha.

Cara pemasaran yang dilakukan adalah dengan membuka warung, gerobak, atau mengunjungi konsumen secara langsung. Kendala yang dihadapi dari UMKM kelompok ini adalah kurangnya pengetahuan dan keterampilan dalam menggunakan teknologi, tidak memiliki rencana/strategi untuk mengembangkan bisnis secara online, tidak memiliki keinginan untuk melakukan bisnis secara online, faktor usia, kurang dukungan dari aspek infrastruktur ICT dan modal, kekurangan tenaga keja terampil, dan juga karena keterbatasan produk yang tidak dapat diproduksi dalam jumlah yang banyak untuk memenuhi pesanan.

- UMKM yang sudah mencoba menggunakan website, media sosial atau marketplace, namun tidak melakukan pengembangan lebih lanjut, atau tidak melakukan keberlanjutan dari penggunaan ICT dalam benusaha tersebut. Hal tersebut disebabkan karena berbagai media tersebut dibuat oleh orang la in (kerabat atau pihak lain), namun pemilik usaha memiliki keterbatasan keterampilan untuk mengelola atau melakukan keberlanjutan dari penggunaan ICT tersebut. Namun untuk media WA dan FB, karena sering digunakan dalam kehidupan seharihari, maka kedua media sosial ini menjadi media yang sering digunakan dalam memasarkan produk secara online.

UMKM yang telah berhasil melakukan bisnis secara online, menggunakan ICT dengan berkelanjutan. Faktor-faktor penyebab keberhasilan dari kelompok UMKM ini adalah karena didukung dengan pengetahuan berbisnis dan keterampilan dalam penggunaan ICT dalam berusaha.

Selanjutnya dari hasil FGD bersama dengan pemerintah Desa Sayang, pelaku usaha, dan tokoh masyarakat Desa
Sayang, diketahui bahwa Desa Sayang sangat berpotensi untuk dikembangkan karena banyak pelaku usaha dan produk di bidang kuliner. Lokasi Desa Sayang juga sangat strategis karena dekat dengan berbagai kampus, dan berada di lokasi yang ramai dilalui kendaraan. Pelaku usaha di Desa Sayang mengemukakan kendala mereka dalam mengembangkan usaha karena masalah persaingan. Banyak pelaku usaha dari pendatang yang membuka usaha di Desa Sayang dengan inovasi yang beragam. Kendala la in yaitu seperti lokasi usaha yang berada digang, ingin pemasaran yang lebih baik, kendala dalam keterampilan menggunakan teknologi, juga kendala sdm untuk melanjutkan usaha. Dari hasil FGD ini juga diketahui berbagai harapan dari pelaku usaha dan masyarakat. Diantara berbagai harapan tersebut, harapan yang terkait dengan dunia usaha adalah pelatihan dalam pembukuan keuangan, pembuatan produk baru, dan meninginginkan pelatihan untuk mendafarkan ke grab food atau go food. Saat ini, belum banyak pelaku usa ha yang memiliki grab food atau go food, padahal Desa Sayang sangat memiliki potensi dengan beragam produk kuliner dengan target pasar yang sangat banyak. Pelatihan pembuatan dan pengoperasian grab food dan go food dianggap sebagai media pemasaran yang paling memungkinkan dan memiliki potensi untuk meningkatkan pendapatan bagi pelaku usaha. Dengan demikian, informasi mengenai penggunaan teknologi informasi, pelatihan dan peningkatan keterampilan bagi pelaku usaha sangat diperlukan da lam pengembangan usa ha.

Pelatihan Digital Marketing dalam Upaya Pengembangan Usaha yang Berbasis Teknologi pada UMKM Desa Sayang Kecamatan J a tinangor.

Berdasarkan pada hasil identifikasi penggunaan teknologi komunikasi dan informasi dalam melakukan usaha di Desa Sayang, maka diperlukan upaya-upaya untuk meningkatkan pengetahuan dan keterampilan bagi para pelaku usaha di Desa Sayang, khususnya mengenai bisnis online dan penggunaan teknologi dalam menjalankan usaha. Dengan demikian, dilaksanakan kegiatan pelatihan yang memiliki tujuan yaiatu : 1) Meningkatkan 
wawasan dan pengetahuan kepada para pelaku usaha (UMKM) Desa Sayang mengenai kewirausahaan, khususnya adalah mengenai bisnis online. 2) Menumbuhan/meningkatkan semangat dan inspirasi kepada para pelaku usaha (UMKM) Desa Sayang dalam menjalankan bisnis online.

Memberikan/meningkatkan keterampilan kepada para pelaku usaha (UMKM) Desa Sayang dalam penggunaan teknologi untuk memasarkan produk (melalui pendaftaraan dan pengelolaan aplikasi grab food dan go food). Berikut adalah sesi materi dari pelatihan digital marketing dalam upaya pengembangan usaha yang berbasis teknologi pada UMKM Desa Sayang Kecamatan J atinangor.

Menumbuhan jiwa kewirausahaan dan Memberikan Insipirasi dari Keberhasilan Bisnis O nline

Dalam sesi pertama, materi yang disampaikan adalah menumbuhkan jiwa kewirausahaan dan memberikan inspirasi dari keberhasilan bisnis online. Pembicara dalam workshop ini adalah pemilik beberapa usaha yang sudah berkecimpung dalam bisnis secara online, dan memiliki berbagai keberhasilan dari bisnis online ini. Pada sesi pertama, pembicara memberikan materi berdasarkan pengalamannya dalam mengelola bisnis online. Beberapa hal yang ditekankan oleh pembicara adalah bahwa dalam berbisnis diperlukan tekad, tidak harus banyak teori, jangan banyak berfikir, tapi harus dijalankan. Inti dari keberhasilan berbisnis adalah pintar membaca peluang, dengan menggunakan modal yang sedikit namun harus kreatif dan pantang menyerah. Pembicara mengemukakan pengalaman dalam berbisnis yang tidak selalu berjalan dengan baik. Pembicara juga menceritakan pengalaman ketika melakukan bisnis dan mengalami kegagalan. Namun, kembali dikemukakan cara untuk bangkit dari kegagalan sampai akhimya dapat menjalankan bisnis dengan sukses.

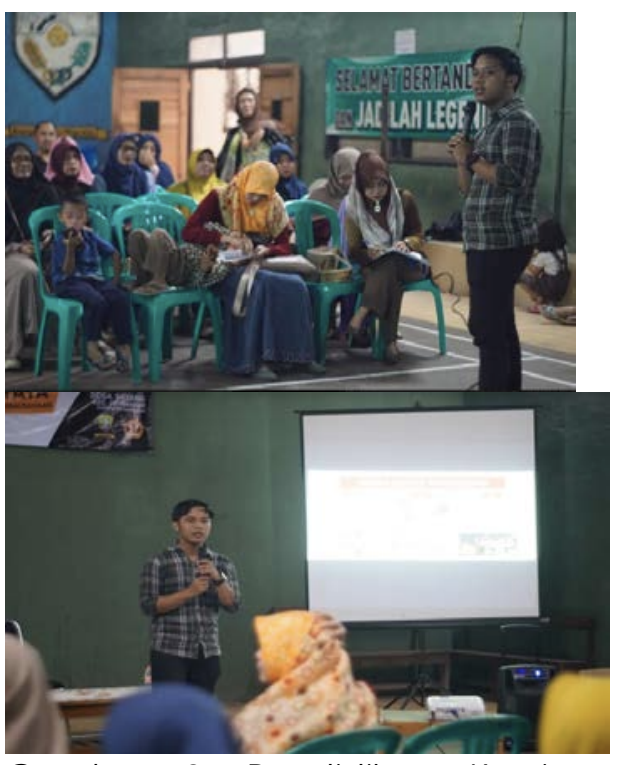

Gambar 2. Pendidikan Kewira usahaan Berbisnis Online dan Pelatihan Penggunaan Teknologi dalam Pengembangan Usaha

Salah satu faktor keberhasilan dalam berbisnis yang dikemukakan oleh pembicara adalah dengan menggunakan teknologi. Teknologi memberikan solusi dan peluang ditengah keterbatasan modal dan sarana la innya. Berbagai usaha yang dimiliki oleh pembicara, memang berkembang salah satunya karena dukungan teknologi. Dikemukakan bahwa pemilik usaha tidak perlu memiliki karyawan yang banyak, tidak perlu memiliki toko yang besar, sehingga dapat menghembat berbagai biaya operasional. Beberapa biaya operasional yang dapat dihemat adalah biaya untuk karyawan pengantar makanan, biaya promosi dan juga biaya pemeliharaan toko. Pemilik usaha bemitra dengan grab food dan go food. Lebih dari setengah penjualan usahanya adalah berasal dari pemesanan melalui grab food dan go food tersebut. Pemilik usaha tidak perlu lagi membuka toko yang lebih besar, atau tidak perlu khusus menggaji karyawan untuk mengantarkan makanan kepada konsumen. Pembicara mengemukakan perbandingan omset antara sebelum menggunakan teknologi dan setelah menggunakan teknologi. Banyak sekali keuntungan dan peningkatan omset setelah menggunakan teknologi dalam melakukan usaha. 


\section{Sha ring Session}

Setelah pemberian materi berbisnis online, maka selanjutnya dilakukan sharing session. Dalam sharing session ini, pelaku usaha mengemukakan pemasalahan yang dihadapainya dalam melakukan usaha, untuk kemudian berdiskusi dengan pembicara untuk tindak lanjut dan upaya mengatasi permasalahan tersebut. Dalam sesi ini diketahui beberapa permasalahan yang dihadapi oleh pelaku usaha di Desa Sayang, yaitu seperti lokasi usaha yang berada di gang. Pemilik usaha ini mengemukakan bagaimana cara agar usaha dapat berkembang namun lokasi berada di gang. Dari hasil diskusi dengan pembicara diketahui bahwa melalui bisnis online, tidak menjadi masalah meskipun lokasi usaha berada di gang. Justru bantuan teknologi akan memudahkan pemasaran meskipun lokasi usaha berada di gang. Hal terpenting yang harus diperhatikan adalah titik lokasi ha rus tepat dapat dibaca oleh google map, dan juga harus terdapat spanduk untuk memudahkan grab food/go food untuk menemukan tempat usaha tersebut meskipun berada digang.

Pelaku usaha lain mengemukakan kemunduran yang sangat drastis dalam usahanya. Dalam sesi ini, pembicara mengemukakan bahwa mengenal usaha yang dijalankan oleh pelaku usaha. Kemunduran yang terjadi disebabkan karena lokasi usaha yang tidak diketahui oleh umum. Selain itu, pelaku usaha tidak menggunakan teknologi, kurang melakukan promosi dan pemasaran sehingga masyarakat tidak mengetahui terdapat usaha makanan di daerah tersebut. Sehingga dalam hal ini dipenlukan inovasi dalam promosi dan pemasaran agar dapat dikenal oleh masyarakat. Minimal dengan menggunakan spanduk yang lebih terlihat, dan menggunakan go food atau grab food agar lebih meningkatkan penjualan.

Lebih lanjut, berdasarkan sharing session ini, diketahui beberapa permasalahan yang dialami oleh pelaku usaha di Desa Sayang adalah karena masalah persaingan dengan pelaku usaha pendatang yang memiliki inovasi dan menggunakan teknologi. Pemasalahan lain adalah masalah permodalan, pemasaran dan promosi produk, lokasi usaha yang tidak di pinggir jalan dan jarang diketahui oleh masyarakat umum, dan kekurangan tenaga kerja karena penduduk di Desa Sayang banyak yang bekerja di pabrik, dengan demikian diperlukan untuk menumbuhkan jiwa wirausaha sejak dari usia dini.

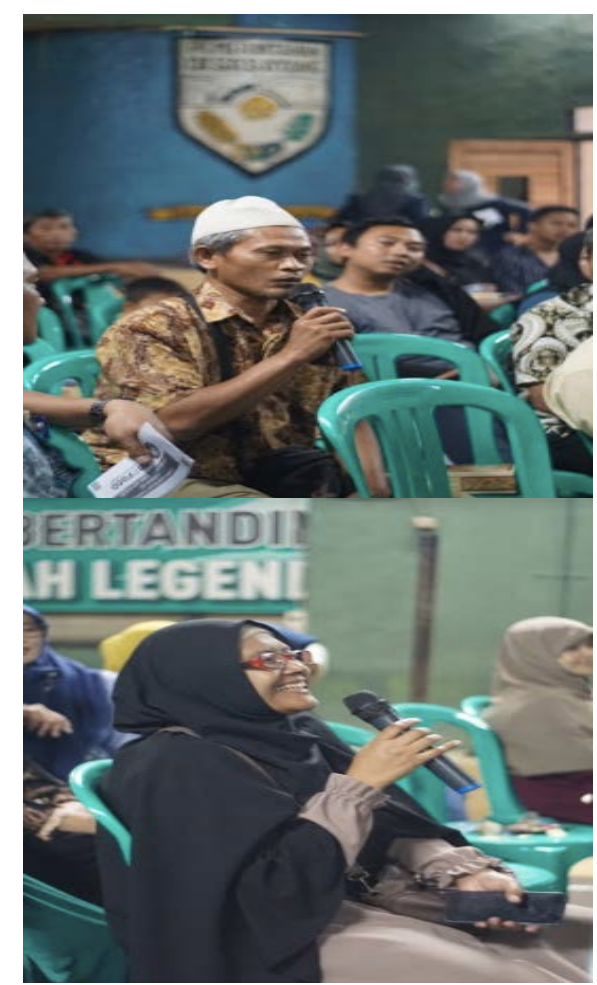

Gambar 3. Sharing Session

\section{Pelatihan Digital Marketing}

Sesi selanjutnya dari upaya peningkatan usaha berbasis teknologi bagi UMKM di Desa Sayang Kecamatan Jatinangor adalah pelatihan digital marketing. Teknologi yang dipilih dalam pelatihan ini adalah grab food dan go food. Alasan pemilihan grab food dan go food adalah berdasarkan pada identifikasi awal. Dari identifikasi awal diketahui bahwa pelaku usaha sudah terbiasa dalam penggunaan WA dan FB. Selain hal tersebut, perangkat keras teknologi yang sering dan lebih banyak digunakan oleh para pelaku usaha adalah handphone. Dari hasil identifikasi juga diketahui bahwa belum ada peserta pelatihan yang sudah bermitra dengan grab food dan go food. Di sisi lain, potensi usaha di Desa Sayang adalah lebih banyak pada produk makanan dengan konsumen banyak tersebar di sekitar kampus dan pada masyarakat sekitar. Teknologi yang 
memungkinkan dengan kondisi dan potensi yang ada adalah dengan menggunakan grab food dan go food. Hasil FGD juga menunjukkan bahwa pelaku usaha ingin mendaftarkan usaha mereka pada grab food dan go food.

Dalam sesi ini, peserta mendapatkan petunjuk langkah demi langkah untuk dapat bemitra dengan grab food dan go food. Seluruh peserta juga mendapatkan buku saku/buku panduan pendaftaran dan penggunaan pada grab food dan go food. Dalam sesi ini peserta mencoba mendaftarkan usahanya, namun karena beberapa kendala persyaratan usaha dan verifikasi dari pihak mitra, maka pendaftaran tidak dapat rampung dalam pelaksanaan pelatihan ini. Meskipun demikian, dalam sesi ini diberikan petunjuk langkah demi langkah sampai akhimya dapat disetujui oleh pihak mitra grab food dan go food.

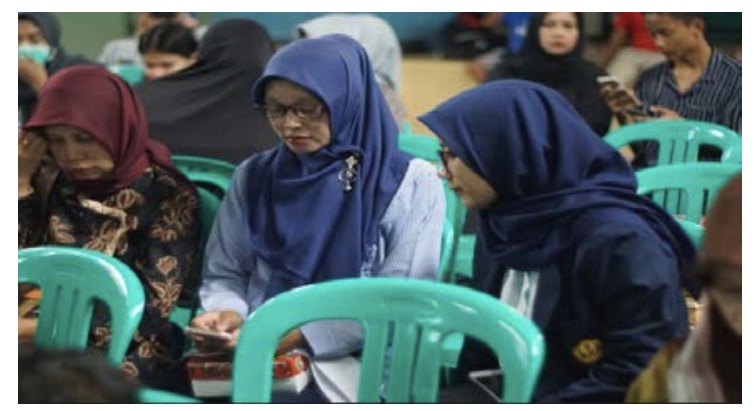

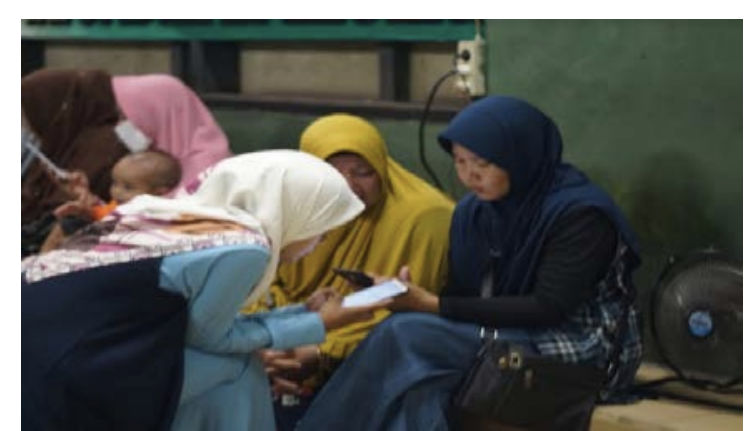

Gambar 4. Praktek Pendaftaran Usaha pada Grab Food dan Go Food

Tanggapan dari Pelaku Usaha Terhadap Pelatihan Digital Marketing

Evaluasi kegiatan ini dilakukan untuk mengetahui tanggapan dari peserta terhadap kegiatan pelatihan yang telah dilakukan. Tanggapan ini dapat dijadikan bahan evaluasi untuk pelaksanaan kegiatan-kegiatan la innya dalam pengembangann usaha di Desa Sayang. Berikut dalam tabel 2 adalah mengenai tanggapan dari pelaku usaha terhadap pelaksanaan pelatihan.

Tabel 2. Tanggapan dari Pelaku Usaha terhadap Pelatihan Digital Marketing

\begin{tabular}{|c|c|c|c|}
\hline Peserta & $\begin{array}{l}\text { Tanggapan } \\
\text { terhadap } \\
\text { pelatihan }\end{array}$ & $\begin{array}{l}\text { Tindak lanjut setelah } \\
\text { mengikuti pelatihan }\end{array}$ & $\begin{array}{l}\text { Pelatihan lain yang } \\
\text { diharapkan untuk } \\
\text { diselenggarakan }\end{array}$ \\
\hline 1 & $\begin{array}{l}\text { Menambah } \\
\text { wawasan }\end{array}$ & $\begin{array}{l}\text { Mempraktekkan } \\
\text { dalam kegiatan usaha }\end{array}$ & $\begin{array}{l}\text { Materi lebih lanjut } \\
\text { mengenai } \\
\text { kewirausahaan }\end{array}$ \\
\hline 2 & $\begin{array}{l}\text { Cukup bagus } \\
\text { karena menambah } \\
\text { wawasan } \\
\text { dalam bidang } \\
\text { pemasaran }\end{array}$ & $\begin{array}{l}\text { Membuka usaha baru } \\
\text { melalui pemasaran } \\
\text { online }\end{array}$ & - \\
\hline 3 & $\begin{array}{l}\text { Sangat } \\
\text { memberikan } \\
\text { inspirasi }\end{array}$ & $\begin{array}{l}\text { Mempraktekan bisnis } \\
\text { online }\end{array}$ & - \\
\hline 4 & $\begin{array}{l}\text { Menambah } \\
\text { wawasan }\end{array}$ & $\begin{array}{l}\text { Lebih semangat untuk } \\
\text { memajukan usaha } \\
\text { melalui teknologi }\end{array}$ & $\begin{array}{l}\text { Cara mendapatkan } \\
\text { pembeli }\end{array}$ \\
\hline 5 & $\begin{array}{l}\text { Sangat } \\
\text { bermanfaat }\end{array}$ & $\begin{array}{l}\text { Belajar usaha } \\
\text { menggunakan } \\
\text { teknologi }\end{array}$ & - \\
\hline 6 & $\begin{array}{l}\text { Sangat bagus, } \\
\text { banyak pelajaran } \\
\text { yang dapat diambil }\end{array}$ & $\begin{array}{l}\text { Akan mencoba seperti } \\
\text { pengalaman trainer, } \\
\text { mencoba dari hal yang } \\
\text { terkecil }\end{array}$ & $\begin{array}{l}\text { Pelatihan mempromosikan } \\
\text { produk }\end{array}$ \\
\hline
\end{tabular}


Sawala: J umal pengabdian Masyarakat Pembangunan Sosial, Desa dan Masyarakat

\begin{tabular}{|c|c|c|c|}
\hline 7 & Sangat bagus & $\begin{array}{l}\text { Mencoba untuk } \\
\text { mengembangkan } \\
\text { usaha }\end{array}$ & $\begin{array}{l}\text { Pengemasan produk yang } \\
\text { aman dan menarik }\end{array}$ \\
\hline 8 & $\begin{array}{l}\text { Sangat } \\
\text { memberikan } \\
\text { semangat }\end{array}$ & $\begin{array}{l}\text { Akan segera } \\
\text { mempraktekkan }\end{array}$ & $\begin{array}{l}\text { Pembuatan produk yang } \\
\text { dapat dijual }\end{array}$ \\
\hline 9 & $\begin{array}{l}\text { Sangat } \\
\text { membantu } \\
\text { perekonomian } \\
\text { rakyat kecil }\end{array}$ & $\begin{array}{l}\text { Akan terus berusaha } \\
\text { dan lebih semangat }\end{array}$ & $\begin{array}{l}\text { Pelatihan yang bisa } \\
\text { memanfaatkan modal } \\
\text { yang kecil }\end{array}$ \\
\hline 10 & $\begin{array}{l}\text { Menambah ilmu } \\
\text { dalam berusaha, } \\
\text { dan menambah } \\
\text { semangat dalam } \\
\text { berusaha }\end{array}$ & $\begin{array}{l}\text { Mencoba untuk lebih } \\
\text { mengembangkan } \\
\text { usaha }\end{array}$ & $\begin{array}{l}\text { Mengelola keuangan } \\
\text { dalam bisnis }\end{array}$ \\
\hline 11 & $\begin{array}{l}\text { Sangat membantu, } \\
\text { menambah ilmu } \\
\text { baru }\end{array}$ & $\begin{array}{l}\text { Lebih ingin } \\
\text { mengembangkan } \\
\text { usaha }\end{array}$ & Cara pemasaran produk \\
\hline 12 & $\begin{array}{l}\text { Sangat bermanfaat, } \\
\text { karena kendala } \\
\text { dalam berusaha } \\
\text { adalah kalah } \\
\text { bersaing dengan } \\
\text { pemilik usaha } \\
\text { online }\end{array}$ & $\begin{array}{l}\text { Mempraktekan usaha } \\
\text { secara online }\end{array}$ & $\begin{array}{l}\text { Pelatihan pengolahan } \\
\text { produk }\end{array}$ \\
\hline 13 & $\begin{array}{l}\text { Sangat baik dan } \\
\text { sangat bermanfaat }\end{array}$ & $\begin{array}{l}\text { Akan dicoba lebih } \\
\text { fokus }\end{array}$ & $\begin{array}{l}\text { Pelatihan sesuai dengan } \\
\text { potensi yang dimiliki Desa } \\
\text { Sayang }\end{array}$ \\
\hline 14 & $\begin{array}{l}\text { Sangat bagus, } \\
\text { membuka pikiran }\end{array}$ & $\begin{array}{l}\text { Memprakłekkan go } \\
\text { food/grab food }\end{array}$ & Menu-menu baru \\
\hline 15 & Cukup menarik & & \\
\hline 16 & $\begin{array}{l}\text { Sangat menarik, } \\
\text { edukatif dan } \\
\text { inspiratif }\end{array}$ & $\begin{array}{l}\text { Akan memulai usaha } \\
\text { online }\end{array}$ & \\
\hline 17 & Menarik & $\begin{array}{l}\text { Mengembangkan } \\
\text { usaha }\end{array}$ & $\begin{array}{l}\text { Pengemasan produk, cara } \\
\text { mengolah produk }\end{array}$ \\
\hline 18 & $\begin{array}{l}\text { Mendapat } \\
\text { tambahan ilmu } \\
\text { untuk } \\
\text { mengembangkan } \\
\text { usaha }\end{array}$ & $\begin{array}{l}\text { Akan terus berusaha } \\
\text { dengan bantuan } \\
\text { teknologi }\end{array}$ & $\begin{array}{l}\text { Pengemasan produk agar } \\
\text { lebih menarik }\end{array}$ \\
\hline 19 & Sangat baik & $\begin{array}{l}\text { Akan kembali } \\
\text { membuka usaha }\end{array}$ & $\begin{array}{l}\text { Pelatihan pembuatan } \\
\text { makanan }\end{array}$ \\
\hline 20 & Bagus & $\begin{array}{l}\text { Mencoba memasarkan } \\
\text { produk melalui media } \\
\text { sosial yang lain }\end{array}$ & $\begin{array}{l}\text { Lebih mendalam } \\
\text { mengenai pemasaran } \\
\text { melalui marketplace }\end{array}$ \\
\hline 21 & Sangat bermanfaat & $\begin{array}{l}\text { Akan lebih berpromosi } \\
\text { dalam berbagai media } \\
\text { sosial dan mendaftar } \\
\text { ke grab food dan fo } \\
\text { food }\end{array}$ & Peluang untuk kerjasama \\
\hline
\end{tabular}




\begin{tabular}{|l|l|l|l|}
\hline 22 & $\begin{array}{l}\text { Sangat bagus, } \\
\text { semoga dapat } \\
\text { berkesinambungan }\end{array}$ & $\begin{array}{l}\text { Mempraktekan dalam } \\
\text { usaha yang sekarang } \\
\text { sedang dijalankan }\end{array}$ & Tentang kewirausahaan \\
\hline
\end{tabular}

\begin{abstract}
Berdasarkan data tersebut diketahui bahwa seluruh peserta memberikan tanggapan yang positif terhadap kegiatan pelatihan ini. Pelatihan dianggap sangat bagus, memberikan wawasan dan tambahan ilmu, memberikan manfaat, dan memberikan inspirasi. Hampir seluruh pelaku usa ha ing in mempraktekan bisnis online ini dalam pengembangan usahanya. Masyarakat juga mengharapkan kegiatan pengembangan usaha ini dilakukan secara berkelanjutan.
\end{abstract}

\section{KESIMPULAN}

Berdasarkan identifikasi awal, diketahui bahwa UMKM di Desa Sayang memerlukan pengembangan dalam usaha dengan menggunakan teknologi agar dapat bersaing dengan usahausaha baru yang berasal dari pendatang. Kondisi pada UMKM di Desa Sayang menunjukkan bahwa UMKM masih menggunakan teknologi sederhana dalam pemasaran, yaitu menggunakan handphone dan didominasi dengan media WA dan FB. Bahkan, masih banyak UMKM yang menjalankan usahanya secara offline tanpa bantuan teknologi. Dengan demikian, upaya yang dilakukan adalah dengan pendidikan kewirausahaan dalam berbisnis online dan pelatihan penggunaan teknologi dalam pemasaran produk (menggunakan grab food dan go food). Hasil dari pelatihan menunjukkan bahwa pelaku usa ha sangat menyambut positif kegiatan ini, memberikan manfaat dan inspirasi, sehingga mereka memiliki rencana tindak lanjut untuk menjalankan usaha secara online.

Masyarakat mengharapkan keberlanjutan dari kegiatan pengembangan UMKM di Desa Sayang. Data mengenai tanggapan masyarakat dapat dijadikan rujukan bagi pihak-pihak lain yang akan melakukan kegiatan pengembangan UMKM di Desa Sayang. Kegiatan lebih lanjut yang dapat dilakukan adalah : pelatihan pengemasan produk, pelatihan pembukuan keuangan, pelatihan pembuatan produk (makanan) yang dapat dijual dan menu-menu baru yang lebih kreatif.

\section{UCAPAN TERIMA KASIH}

Terima kasih yang sebesarbesamya kepada pihak Universitas Padjadjaran atas bantuan dana PPM tahun anggaran 2020. Terima kasih juga kepada tim mahasiswa Kuliah Kerja Nyata (KKN) Tematik Kewirausahaan Universitas Padjadjaran Tahun 2020 di Desa Sayang Kecamatan J atinangor.

\section{DAFIAR PUSTAKA}

Alford, P \& Page, S.J (2015) Marketing technology for adoption by small business. The service Industries Joumal, 2015 Vol. 35, Nos. 11-12, 655-669

Baladraf, M.I.F., Sembodo, G., Hasanah, L.U \& Pramono. A. (2018). Pelatihan Sukses Berbisnis Online Memajukan Perekonomian Masyarakat Melalui Pemasaran Online Putat Jaya Surabaya. Jumal Abdikarya : Jumal Karya Pengabdian Dosen dan Mahasiswa, Februari 2018 Vol 01 No 1

Bird, D. (2007). Commonsense Direct \& Digital Marketing. London : Kogan Page.

Cant, M.C \& Wiid, J.A (2016). The use of traditional marketing tools by SMEs in an emerging economy: a South African perspective. Problems and Perspectives in Management, Volume 14, Issue 1, 2016

Chaffey, D \& Smith, P.R (2008). e-Marketing Excellence : Planning and optimizing your digital marketing. USA : Elsevier.

Djamaludin., Aviasti., Rukmana, A.N \& Rukmana, O. (2016) Peningkatan Kemampuan Usaha Kecil Menengah di Wilayah Bandung Raya dalam Pemanfaatan Intemet Sebagai Sarana Pemasaran dan Perluasan Jangkauan Pasar. Ethos (Jumal Penelitian dan Pengabdian 


\begin{tabular}{|c|c|c|}
\hline $\begin{array}{c}\text { Sawala: Jumal pengabdian Masyarakat } \\
\text { Pembangunan Sosial, Desa dan Masyarakat }\end{array}$ & $\begin{array}{c}\text { Volume 1, Nomor 2, Agustus 2020 } \\
\text { Halaman 36-50 }\end{array}$ & e ISSN: 2716-4705 \\
\hline
\end{tabular}

Masyarakat). Vol 4, No.1, Januari 2016

Gibson, C. (2018). The Most Effective Digital Marketing Strategies \& Approaches : A Review of Literature. Intemational J oumal of Scientific and Research Publications, Volume 8, Issue 2, February 2018

Kumiawan, A \& Asharudin, M (2018). Small and Medium Enterprises (SMEs) Face Digital Marketing. Muhammadiyah Intemational Joumal of Economics and Business Volume 1, Number 2, December 2018

Mulyana, N (2016). Need Assessment Masyarakat Sekitar Kampus Jatnangor. Social Work Jumal. Vol. 6 Nomor 1

Oktafiyani, F \& Rustandi, D (2018). Digital Marketing dalam Membangun Brand Awareness. PRofesi Humas, Volume 3, No. 1, 2018, hlm. 1-20

Permana, S.H (2017) Strategi Peningkatan Usaha Mikro, Kecil dan Menengah (UMKM) di Indonesia. Aspira si Vol. 8 No. 1, J uni 2017

Rowan, W. (2002) Digital Marketing : Using New Technologies to Get Closer to Your Customers. London : Kogan Page

Ryan, D \& J ones, C (2009) Understanding Digital Marketing : Marketing strategies for engaging the digital generation. London : Kogan Page

Setia wati, I \& Widyartati, P (2017) Pengaruh Strategi Pemasaran Online Terhadap Peningkatan Laba UMKM. Seminar Nasional dan Call for Paper 2017 Strategi Pengembangan Sumber Daya Manusia Melalui Publikasi Jumal Ilmiah dalam Menyikapi Pemenristekdikti Rl No.20 Tahun 2017

Taiminen, H.M \& Karjaluoto, H (2014). The usage of digital marketing channels in SMEs. J oumal of Small Business and Enterprise Development Vol. 22 No. 4, 2015 pp. 633-651

Widyaningrum, P.W \& Bharata, W (2017). Workshop Intemet Dan Digital Marketing Untuk Meningkatkan
Daya Saing Pada Kelompok Pengusaha Muda Ponorogo. Jumal pengabdian kepada masyarakat ADIMAS vol.1 no. 1.Ma ret.Tahun 2017

Weber. L (2009) Marketing to The Social Web : How Digital Customer Communities Build Your Business. Canada : J ohn Wiley \& Sons, Inc.

Yasmin, A., Ta sneem, S \& Fatema, K (2015). Effectiveness of Digital Marketing in the Challenging Age: An Empirical Study. Intemational Joumal of Management Science and Business Administration. Volume 1, Issue 5, April 2015, Pages 69-80 